\title{
CYTOTOXIC ACTIVITY OF BRAZILEIN ISOLATED FROM SECANG (CAESALPINIA SAPPAN L.) AGAINST MCF7/DOX CELLS BY INHIBITION OF P-GLYCOPROTEIN
}

\author{
N. P. LINDA LAKSMIANI'*, E. D. Y. MEIYANTO², R. ASMAH SUSIDARTI²
}

${ }^{1}$ Department of Pharmacy, Faculty of Mathematics and Science, Universitas Udayana, Bali, ${ }^{2}$ Cancer Chemoprevention Research Center, Faculty of Pharmacy, Universitas Gadjah Mada, Yogyakarta

Email: lindalaksmiani@gmail.com

Received: 10 May 2017 Revised and Accepted: 02 Nov 2017

\section{ABSTRACT}

Objective: This study was focused on isolation of brazilein from the dried heartwood of Secang (Caesalpinia sappan L.) followed by its characterization using Infrared (IR) spectroscopy, liquid chromatography-mass spectrometry (LC-MS) with electrospray ionization (ESI), proton $\left({ }^{1} \mathrm{H}\right)$, carbon-13 $\left({ }^{13} \mathrm{C}\right)$ nuclear magnetic resonance (NMR) and two dimensional (2D)-NMR, evaluation the cytotoxic activity of brazilein in MCF-7 resistant doxorubicin (MCF-7/DOX) cells and evaluate the interaction between brazilein and ATP with P-glycoprotein (Pgp) in silico using molecular docking.

Methods: Brazilein was isolated and purified from ethyl acetate fraction by flash silica gel column chromatography, eluting with chloroform, ethyl acetate and methanol in gradient concentration. In the cytotoxicity assay, MCF-7/DOX cells were cultured in the presence of brazilein for 24 hour (h) and cell viability was evaluated by using 3-(4,5-dimethylthiazol-2-yl)-2,5-diphenyl tetrazolium bromide (MTT) assay. Interactions between brazilein and the target proteins were evaluated and calculated in silico by molecular docking using PLANTS.

Results: The infrared, mass spectra with a molecular weight of 284 and NMR signal confirmed that was brazilein. MTT assay showed a dosedependent inhibition of MCF-7/DOX cell proliferation with brazilein IC ${ }_{50}$ value of $43 \mu \mathrm{M}$. The docking score of brazilein was-71,45 kcal/mol and ATP value-96,23 kcal/mol.

Conclusion: Brazilein has a potent cytotoxic value on MCF-7/DOX and high affinity in Pgp protein target. Brazilein can be developed as anticancer especially in cancer resistance incidence. Further study must be established to evaluate the molecular mechanism of brazilein inhibit MCF-7/DOX cell proliferation in vitro.

Keywords: Isolation, Brazilein, Cytotoxic, MCF-7/DOX, Pgp

(C) 2017 The Authors. Published by Innovare Academic Sciences Pvt Ltd. This is an open-access article under the CC BY license (http://creativecommons.org/licenses/by/4.0/) DOI: http://dx.doi.org/10.22159/ijpps.2017v9i12.19861

\section{INTRODUCTION}

Brazilein has been already isolated and purified from methanolic extract heartwood of secang by preparative HPLC using ODS-3 column and acetonitrile: isopropanol $(65: 35 \mathrm{v} / \mathrm{v})$ as mobile phase [1]. In this study, brazilein is isolated, purified by using flash column chromatography and characterized using UV-Vis, infrared, mass spectra and NMR signal. Flash column chromatography has several advantages than preparative HPLC such as less expensive, this method do not require the help of expensive machinery, low maintenance, cost effective and available in many laboratories. This finding method for isolation and purification of brazilein by flash column chromatography can be utilized for production of brazilein standard for the laboratory. Therefore flash column chromatography could be an alternative method to isolate this active compound with high purity.

Secang (Caesalpinia sappan L.) has been traditionally used as coloring agent in foods and beverages. Besides, secang has a lot of pharmacological effects such as anti-inflammation [2], antioxidant [3], antimicrobial activities [4], antiacne [5] and anticancer [6]. Several phenolic compounds are isolated from $C$. sappan, such as homo-isoflavonoid protosappanin A, protosappanin B, 4-0methylsappanol, caesalpin J, brazilin, and brazilein [7]. Brazilin and brazilein are the major compounds of this plant proven to be responsible for its pharmacological effects. Brazilein was reported to have a cytotoxic effect on lung cancer cells, nasopharyngeal cancer cells and prostate cancer cells with $\mathrm{IC}_{50}$ value 5-18 $\mu \mathrm{M}$ [8] and caused cell cycle arrest at the G1 phase in MCF-7 cells [9]. Brazilein inhibit HER-2 activation on MCF-7/DOX cells. MCF-7/DOX cells were cells model of breast cancer cell resistance to chemotherapeutic agents [10]. One of the chemotherapeutic agents that is common to be used in breast cancer therapy is doxorubicin. However, several problems come up after the use of doxorubicin such as its toxicity to normal tissues, severe side effects, and developed resistance. Doxorubicin induces the expression of Pgp [11]. Pgp is a transporter belong to ATP-binding cassette (ABC) family [12]. These transporters function as efflux pumps of chemotherapy agent to extracellular with ATP binding [13]. In MCF-7 breast cancer cell cases, overexpression of Pgp could be reduced the chemotherapy agent concentration intracellular that influence decreasing its cytotoxicity activity through efflux mechanism [14]. Pgp is an important transporter that plays role in resistance breast cancer mechanism. For that reason, these transporter is one of protein target therapy to overcome the resistance breast cancer cases. To our knowledge and literature survey, there is no discussion and evaluation about the cytotoxic activity of brazilein on MCF-7/DOX cells through Pgp inhibition. This study was conducted to isolate brazilein from the dried heartwood of secang and to evaluate its cytotoxic effect on resistant breast cancer cells using MCF-7/DOX cells by inhibition of pgp.

\section{MATERIALS AND METHODS}

\section{Sample}

Brazilwood or 'kayu secang' (Caesalpinia sappan L.) was obtained in the form of dried heartwood powder from Center for Research and Development of Medicinal Plants and Traditional Medicines in Tawangmangu Indonesia.

\section{Extraction and fractionation of kayu secang}

The dried heartwood powder of secang was extracted with methanol (Merck) at a volume ratio of 1:10 (for $48 \mathrm{~h}$, at room temperature). The methanolic extract was then concentrated under 
reduced pressure by rotary evaporator. The extract was partitioned with n-hexan and ethyl acetate (Sigma Aldrich co. USA.) by liquidliquid extraction (LLE). The ethyl acetate fraction was evaporated using a rotary evaporator to yield crystal.

\section{Isolation and purification of brazilein in ethyl acetate fraction of kayu secang by silica gel column chromatography}

The ethyl acetate fraction of kayu secang was separated by flash silica gel column chromatography using chloroform-ethyl acetatemethanol eluent with gradient concentration (varying from nonpolar until polar eluent). The fraction was collected every $30 \mathrm{ml}$ and each fraction was evaluated and monitored by thin layer chromatography (TLC) profile using silica gel as the stationary phase and chloroform: ethyl acetate: methanol (1:7:2) as the mobile phase. The crude fraction was then purified using flash silica gel column chromatography again with the same mobile system. The pure fraction was obtained if gave one red spot in TLC profile and evaluated by TLC densitometry and Liquid Chromatography gave one peak area.

\section{Characterization of brazilein}

The purified brazilein was characterize using UV-Vis spectrophotometry, Infrared spectrophotometry, LC-MS, ${ }^{13} \mathrm{C}-\mathrm{NMR},{ }^{1} \mathrm{H}-\mathrm{NMR}$ and $2 \mathrm{D}$ NMR $\left({ }^{1} \mathrm{H}-{ }^{-1} \mathrm{H}\right.$ COZY, ${ }^{1} \mathrm{H}^{-13} \mathrm{C} \mathrm{HMQC}$ and $\left.{ }^{1} \mathrm{H}-{ }^{-13} \mathrm{C} \mathrm{HMBC}\right)$.

\section{Cell culture}

The MCF-7/DOX cells used are the collection of Cancer Chemoprevention Research Center (CCRC), Universitas Gadjah Mada, transferred from Nara Institute of Science and Technology (NAIST), Japan. The cells were cultured in DMEM (Gibco) Culture Media containing 10\% Fetal Bovine Serum (FBS) (Gibco), 1\% penicillin-streptomycin, and $0.5 \%$ fungizone. Trypsin-EDTA $0.25 \%$ (Gibco) was used in cell harvest [15].

Cytotoxicity and cell viability assay: 3-(4, 5-dimethylthiazol-2yl)-2,5-diphenyltetrazolium bromide (MTT) assay

MTT cytotoxicity assay was used to examine the effect of an isolated compound as a sample on MCF-7/Dox cells. Cells were distributed to 96-well plate with denstity of $5 \times 10^{3}$ cells/well and incubated in $37^{\circ} \mathrm{C}$ with $5 \% \mathrm{CO}_{2}$ for $24 \mathrm{~h}$. Certain concentrations of the sample were then applied. After $24 \mathrm{~h}$ incubation, 3-[4, 5-dimethylthiazole-2-yl (-2, 5-diphenyltetrazolium bromide)] (MTT) dissolved in PBS as MTT reagent was applied, followed by $4 \mathrm{~h}$ incubation. Stopper reagent, a solution of $10 \% \mathrm{v} / \mathrm{v}$ Sodium Dodecyl Sulphate (SDS) (Merck) dissolved in $0.1 \mathrm{~N} \mathrm{HCl}$ (Merck), was then applied. The plate was then kept with protection from light overnight, continued with absorbance determination ( $\lambda 595 \mathrm{~nm}$ ) using ELISA reader (Bio-Rad). During the process, Phosphate Buffer Saline (PBS) pH 7.4 containing $\mathrm{KCl}$ (HPLC grade, Sigma). $\mathrm{NaCl}$ (HPLC grade, Sigma), $\mathrm{Na}_{2} \mathrm{HPO}_{4}$ (HPLC grade, Sigma) and $\mathrm{KH}_{2} \mathrm{PO}_{4}$ (HPLC grade, Sigma) dissolved in aquadest was used washing reagent.

\section{Molecular docking}

In this study, the docking of brazilein to pgp was observed, using ATP as a comparison. Ligands preparation were done by using Marvin Sketch. The structure of pgp (1MV5) proteins were taken from Protein Data Bank (PDB). Protein preparation was done by using YASARA. Molecular docking was conducted by using PLANTS (Protein-Ligand Ant System) Software, giving docking score as a result.

\section{RESULTS}

\section{Extraction and fractionation of kayu secang}

The methanolic extract of kayu secang was obtained $10.24 \% \mathrm{~b} / \mathrm{b}$ and then this extract was applied to fractionation using liquid-liquid extraction (LLE) with n-hexan and ethyl acetat. Hexan was used to reduce and eliminate the lipid, resin and non-polar component in the methanolic extract of kayu secang. The ethyl acetat fraction was obtained after concentrated using a rotary evaporator to reddish yield crystal as much $2.3 \% \mathrm{~b} / \mathrm{b}$.

\section{Isolation and purification of brazilein in kayu secang by silica gel column chromatography}

Vacuum column chromatography by using silica gel and chloroformethyl acetate-methanol (varying concentration) as a mobile phase was performed to separate the components in the ethyl acetate fraction. The mobile phase was chosen based on the different polarities of each eluent, hopefully, the fraction that obtained from this method more pure. Each fraction was collected at volume $30 \mathrm{ml}$ and obtained 115 fractions. This fraction was evaluated by TLC profile for each fraction and fraction that have same chromatographic profile was collected into one bottle. From this process, 115 fractions could be separated further into 10 fractions. Fraction II-VI was collected into one bottle because fractions have same TLC profile. One of the several spots in the same track on TLC profile gave a red spot dominantly and it was predicted as brazilein.

This crude fraction was chromatographed again by using the same system. The fraction was collected every $30 \mathrm{ml}$ and evaluated the TLC profile. This purification process obtains 16 fractions. Fraction no II gave one red spot. It was evaporated by using a rotary evaporator to reddish crystal as much as $0.007 \% \mathrm{~b} / \mathrm{b}$.

To ensure that fraction no II from purification process was really pure, the purification assay was performed. The purified component was applied in TLC method using silica gel $60 \mathrm{~F}_{254}$ with three different mobile phase system (n-hexan: chloroform: methanol: acetat acid $=2: 7: 1: 1 \mathrm{v} / \mathrm{v}(1)$; chloroform: methanol: acetate acid $=$ 5:1:1 v/v (2); and chloroform: methanol: aquadest: acetate acid $=$ $6: 3: 1: 1 \mathrm{v} / \mathrm{v}(3))$. This compound gives one spot to all system that used. Chromatogram result showed that hRf of this compound in the mobile system no 1 was 40 and hRf in the mobile system no 2 was 60 and the last system gave hRf value as much as 87.5. TLCdensitometry profile of this compound showed one dominant peak in $\lambda 329 \mathrm{~nm}$. It was subjected to further characterization.

\section{Characterization of brazilein}

Isolate compound that obtained from purification process, was characterized by UV-Vis spectrophotometer, FTIR, ESI mass spectrometer and NMR spectrometer.

Its UV-Vis spectra (fig. 1) showed isolate in methanol has maximum absorption in wavelength $287.5 \mathrm{~nm}, 368 \mathrm{~nm}, 435.5 \mathrm{~nm}$ and 588.5 $\mathrm{nm}$. Very strong absorption at $287.5 \mathrm{~nm}$ revealed that isolate has an aromatic group with $\pi \rightarrow \pi^{*}$ transition [16]. Brazilein have one benzene ring that been fusion with dihydropirane ring. Peak at 368 $\mathrm{nm}$ indicates as an unsaturated keton that conjugated [16]. Brazilein also has its functional group. Isolate also has an absorption at 435.5 and $588.5 \mathrm{~nm}$ that means isolate has a long chromophore and auxochrome in its structure [16,17]. Auxochrome bind to chromophore system that makes the compound transition into bathochromic transition.

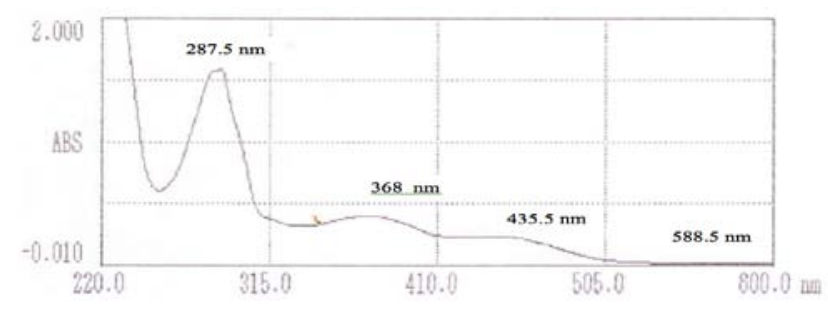

Fig. 1: UV-Vis spectra of isolate in methanol solvent by using spectrophotometer milton roy spectronic 3000 array 
Spectra (fig. 2) showed a wide peak at $3307.9 \mathrm{~cm}^{-1}$. It indicated isolate has a-OH (hydroxyl) functional group, very strong absorption at $1662,6 \mathrm{~cm}^{-1}$ showed the component has a carbonyl functional group $(\mathrm{C}=0) . \mathrm{C}=0$ group is an important infrared spectra characterization of brazilein that could be distinguished by brazilin, the other major compound of kayu secang [18]. The other absorption with strong and sharp absorption at $1604.8 \mathrm{~cm}^{-1}$ showed isolate has a $\mathrm{C}=\mathrm{C}$ functional group from the aromatic ring. Some functional group that explained which present in the structure of brazilein as a predicted component. However, this estimation needs further confirmation by ESI-MS instrument to confirm its molecular weight.

The result of mass spectra analysis of isolate was shown in fig. 3 . The spectra were in positive ion mode. There was 2 peak with high intensity in $\mathrm{m} / z 287$ and $\mathrm{m} / z$ 285. Peak in $\mathrm{m} / z 285$ suitable with $[\mathrm{M}+\mathrm{H}]+$ ion formula, by calculating the formula, we found the mass of isolate was 284. Brazilein with molecular structure $\mathrm{C}_{16} \mathrm{H}_{12} \mathrm{O}_{5}$ have molecular weight 284. This observation confirmed that isolate was brazilein, the major dyestuff component in kayu secang extract with molecular weight 284. This result was suitable with the other literature that brazilein is known to have a molecular weight of 284 [19-20].

The other highly intensity peak, $m / z 287$ was suggested that an artefac with $[\mathrm{M}+3 \mathrm{H}]+$ ion formula. In mass spectra, there was the reaction of molecule sample because of availability of the energy. Brazilein could have reduction process by binding 2 hydrogen atoms with still be neutral molecules and then this reduction molecule could receive 1 proton $\mathrm{H}^{+}$, that could be seen in $m / z 287$ as $[\mathrm{M}+3 \mathrm{H}]^{+}$.

Identification of isolate could be held by using one dimension of NMR Spectroscopy ( $\left.{ }^{1} \mathrm{H}-\mathrm{NMR},{ }^{13} \mathrm{C}-\mathrm{NMR}, \mathrm{DEPT}\right)$ and two dimensions (HMQC, COSY and HMBC). DEPT spectra of isolate shown in table 1. Isolate had five olefinic methane groups signal in $\delta 132.3 ; 112.9$; 112.5; 110.0 and 104.3 and two methylene groups' signal in $\delta 70.9$ and 43.0. Based on HMQC spectra (table 1), two protons in methylene groups were not equivalent to each other. This phenomenon was caused by crossing peak between $\delta 70.9$ carbon resonance signal and proton resonance signal in $\delta 3.92$ and $\delta 3.68$. The other signal was carbon resonance signal $\delta 43.0$ crossing peaks with proton resonance signal in $\delta 3.01$ and $\delta 2.76$.

The ${ }^{1} \mathrm{H}$ NMR spectra of isolate showed that isolate had seven different proton environment, five was an olefinic methane proton and two proton was a methylene signal, $\delta 3.68(1 \mathrm{H})$ and $3.92(1 \mathrm{H})$ were assigned to H-6. Signal at $\delta 2.76(1 \mathrm{H})$ and $3.01(1 \mathrm{H})$ as a H-7. The olefinic proton signal at $\delta 6.46$ was ortho coupled with the signal at $\delta 7.18(\mathrm{~J}=8.0 \mathrm{~Hz})$ and was meta coupled with $\delta 6.28(\mathrm{~J}=2.6$ $\mathrm{Hz}$ ). Therefore, these three olefinic signals were assigned to $\mathrm{H}-2, \mathrm{H}-1$ and $\mathrm{H}-4$, respectively. $\mathrm{H}-8$ and $\mathrm{H}-11$ were assigned by 2D NMR such as HMQC, HMBC and ${ }^{1} \mathrm{H}-{ }^{1} \mathrm{H}$ COZY correlations.

H-8 and H-11 were assigned by HMBC correlations as shown in fig. 4. The proton at $\delta 6.59(1 \mathrm{H})$ as $\mathrm{H}-11$. $\mathrm{H}-11$ has a long-range correlation with C-12 at $\delta_{\mathrm{C}} 137.5$. C-12 was correlated with a proton at $\delta 3.92$ (H-6"b) and 2.76 (H-7`). Four olefinic protons were known as $\mathrm{H}-1, \mathrm{H}-2, \mathrm{H}-4$ an $\mathrm{H}-11$ that means the remained olefinic proton as $\mathrm{H}-8$ at $\delta 6.70(1 \mathrm{H})$.

\section{Brazilein performed cytotoxic activity on MCF-7/DOX cells}

The cytotoxicity of brazilein on MCF-7/DOX cells was determined by using MTT assay. This assay is based on the reduction of the soluble yellow tetrazolium salt to a purple insoluble formazan product by mitochondrial succinic dehydrogenase which can be measured spectrophotometrically after dissolving in SDS solution [21]. The IC $_{50}$ value was $43 \mu \mathrm{M}$ (fig. 5). A potent cytotoxic activity was exhibited by brazilein against MCF-7/DOX cells.

\section{Brazilein potentially inhibits the protein target pgp}

Validation result from Pgp protein showed molecular docking protocol for that protein target could be accepted with RMSD value $<2{ }^{\circ} \mathrm{A}$ (table 2 ) and molecular docking brazilein to Pgp could be continued. The result of molecular docking showed the binding energy of brazilein to Pgp was-71.45 and ATP as a native ligan had binding energy with Pgp was-96.23 (table 2). Interaction between brazilein and ATP with Pgp (PDB ID 1MV5) showed in fig. 6.

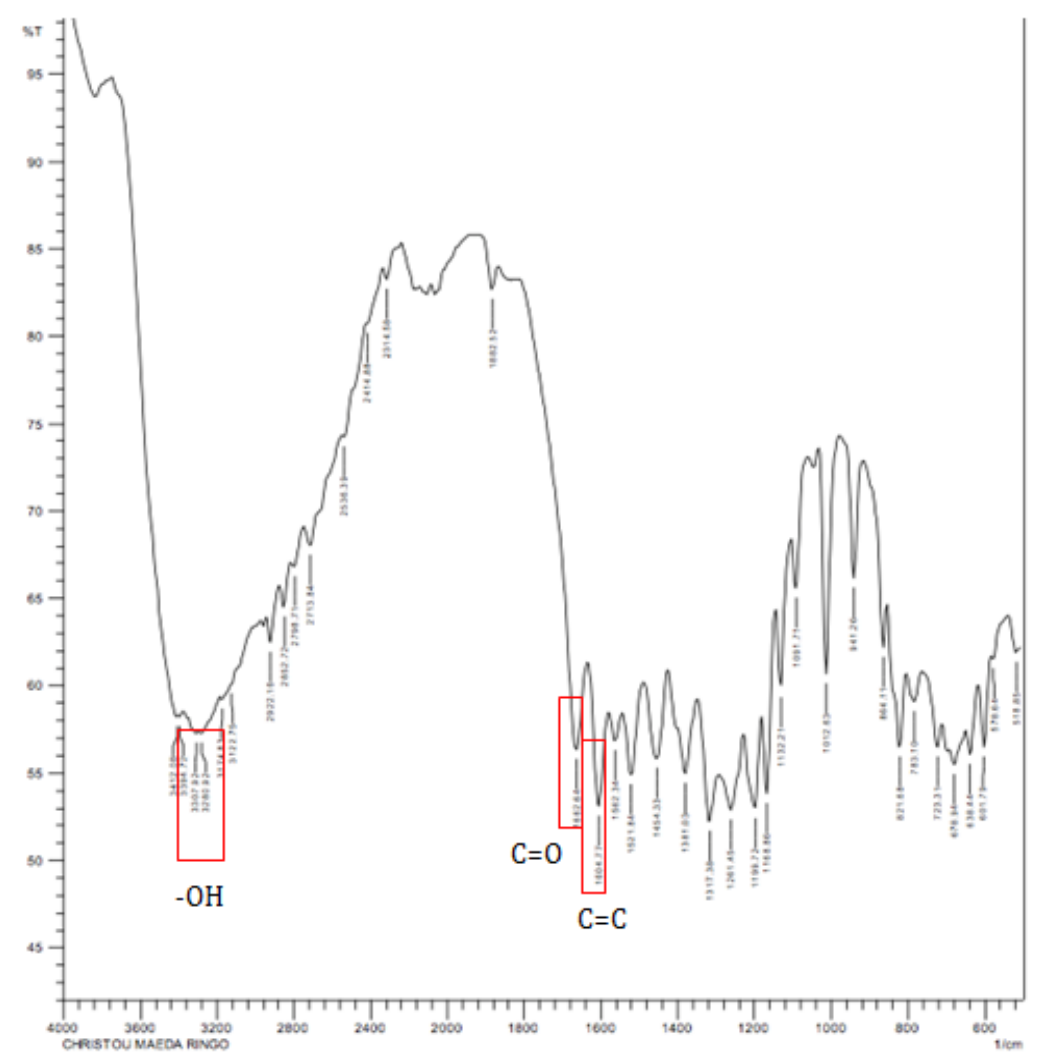

Fig. 2: Infrared spectra of isolate that isolated from ethyl acetate fraction by silica gel column chromatography 


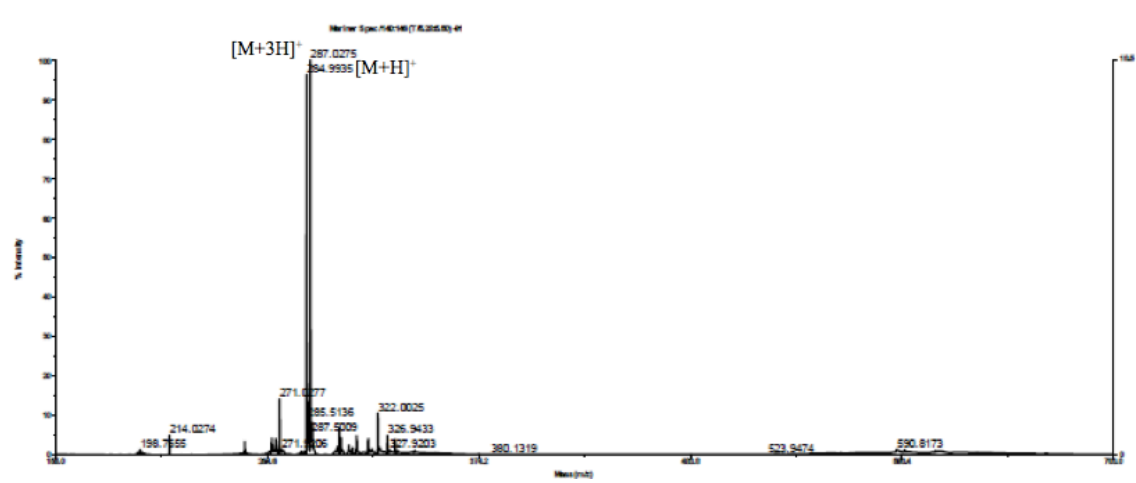

Fig. 3: Mass spectra of isolate

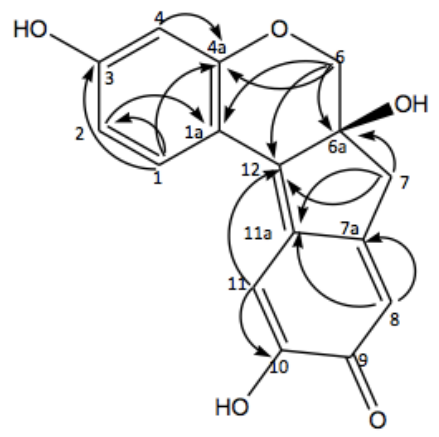

Fig. 4: HMBC correlations of isolate

Table 1: NMR spectra of brazilein by using $\mathrm{CD}_{3}-\mathrm{OD}$ solvent and DELTA2 instrument with $500 \mathrm{MHz}$

\begin{tabular}{|c|c|c|c|c|}
\hline $\mathbf{C} / \mathbf{H}$ & $\left.\delta_{\text {c }(p p m]}(\mathrm{DEPT})\right)$ & ${ }^{\delta} \mathrm{H}(\mathrm{ppm})(\mathrm{Nh}, \mathrm{m}, \mathrm{j})$ & COSY & ${ }^{1} \mathrm{H}-{ }^{13} \mathrm{C}$ HMBC \\
\hline 1 & $132,3(\mathrm{CH})$ & $7,18(1 \mathrm{H}, d, 8,0)$ & $\mathrm{H} 1-\mathrm{H} 2$ & $\mathrm{H} 1-\mathrm{C} 3 / \mathrm{C} 4 \mathrm{a}$ \\
\hline $1 \mathrm{a}$ & $115,6(\mathrm{Cq})$ & - & - & - \\
\hline 2 & $110,0(\mathrm{CH})$ & $6,46(1 \mathrm{H}, d d, 8,0,2,6)$ & $\mathrm{H} 2-\mathrm{H} 1$ & $\mathrm{H} 2-\mathrm{CLa} / \mathrm{C} 4$ \\
\hline 3 & $158,0(\mathrm{Cq})$ & - & - & - \\
\hline 4 & $104,3(\mathrm{CH})$ & $6,28(1 \mathrm{H}, d, 2,6)$ & - & $\mathrm{H} 4-\mathrm{Ca}$ \\
\hline $4 a$ & $155,8(\mathrm{Cq})$ & - & - & - \\
\hline 6 & $70,9\left(\mathrm{CH}_{2}\right)$ & $\begin{array}{l}3,68(1 \mathrm{H}, \mathrm{d}, 11,65) \\
3,92(1 \mathrm{H}, d, 11,65)\end{array}$ & H6'-H6" & $\mathrm{H6"-Cla/C4a/C6a/C12}$ \\
\hline $6 a$ & $78,2(\mathrm{Cq})$ & - & - & - \\
\hline 7 & $43,0\left(\mathrm{CH}_{2}\right)$ & $\begin{array}{l}2,76(1 \mathrm{H}, \mathrm{d}, 16,2) \\
3,01(1 \mathrm{H}, \mathrm{d}, 16,2)\end{array}$ & H7'-H7" & $\begin{array}{l}\text { H7"-C6/C6a/11a } \\
\text { H7'-C6/C6a/11a/C12 }\end{array}$ \\
\hline $7 a$ & $145,8(\mathrm{Cq})$ & - & - & - \\
\hline 8 & $112,5(\mathrm{CH})$ & $6,70(1 \mathrm{H}, \mathrm{s})$ & - & $\mathrm{H} 8-\mathrm{C} 7 \mathrm{a} / \mathrm{C} 11 \mathrm{a}$ \\
\hline 9 & $209,3(\mathrm{Cq})$ & - & - & - \\
\hline 10 & $145,5(\mathrm{Cq})$ & - & - & - \\
\hline 11 & $112,9(\mathrm{CH})$ & $6,59(1 \mathrm{H}, \mathrm{s})$ & - & $\mathrm{H} 11-\mathrm{C} 10 / \mathrm{C} 12$ \\
\hline $11 \mathrm{a}$ & $131,4(\mathrm{Cq})$ & - & - & - \\
\hline 12 & $137,5(\mathrm{Cq})$ & - & - & - \\
\hline
\end{tabular}

$C q=$ Quarternary carbon, $J=$ Coupling constantan, $\mathrm{H}=$ Amount of proton

Table 2: Docking score obtained after docking of brazilein to HER-2

\begin{tabular}{ll}
\hline & Score docking Pgp (1MV5) \\
\hline RMSD (Root Mean Square Deviation) & $1.25^{\circ} \mathrm{A}$ \\
ATP & -89.72 \\
Brazilein & -77.73 \\
\hline
\end{tabular}

Table 3: Interaction brazilein and ATP to pgp protein with amino acid residue in pgp

\begin{tabular}{llll}
\hline Target proteins & Compound & Amino acid residue & Bonding formation \\
\hline Pgp (1MV5) & ATP & Phe 421 & Hydrogen Bond \\
& & Leu 533 & Hydrogen Bond \\
& Brazilein & Ser 423 & Hydrogen Bond \\
& & Asp 505 & Hydrogen Bond \\
& & Leu 504 & Hydrogen Bond \\
\hline
\end{tabular}




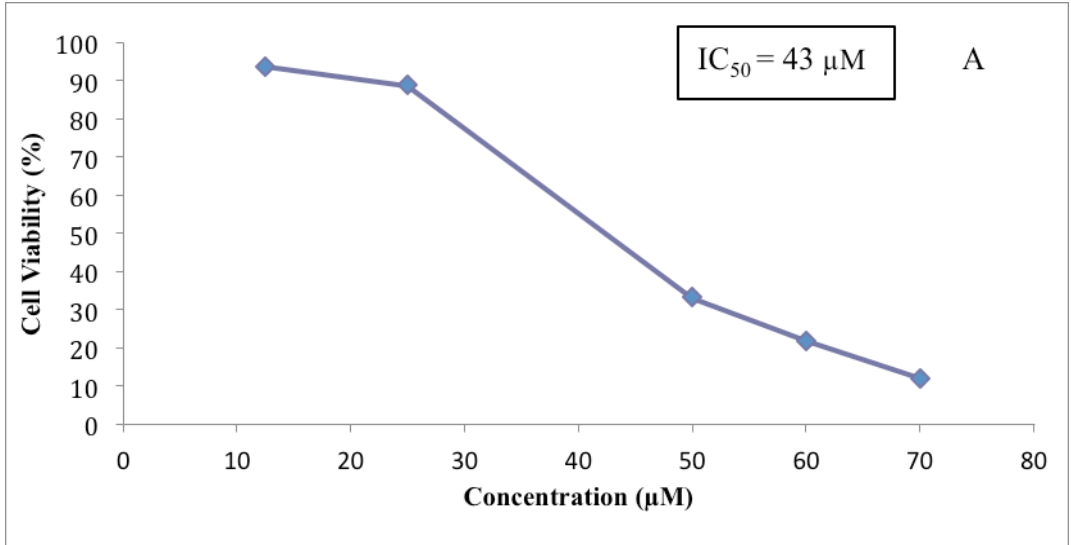

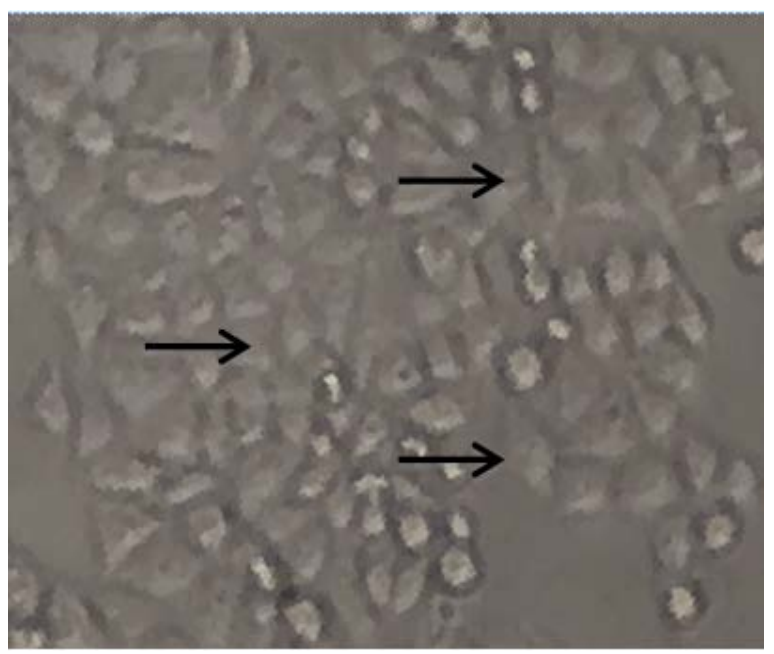

B1

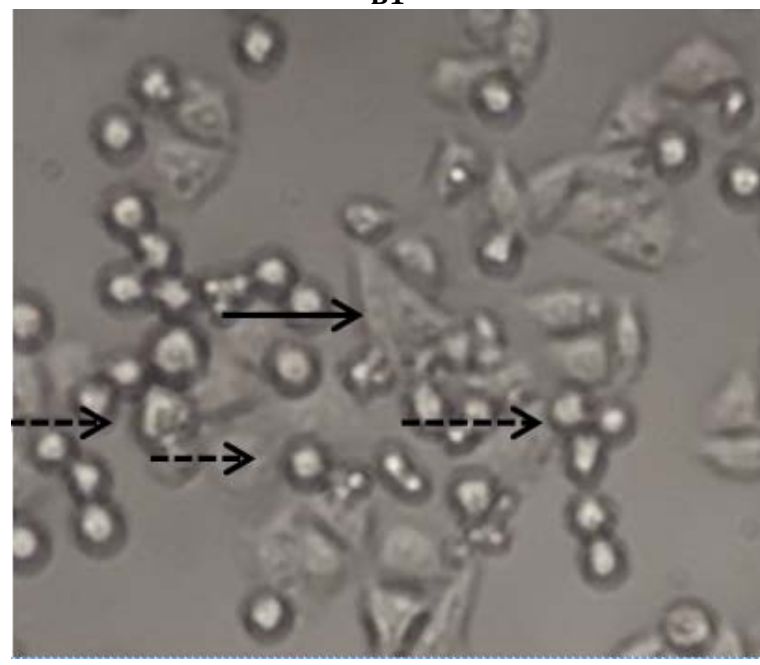

B3

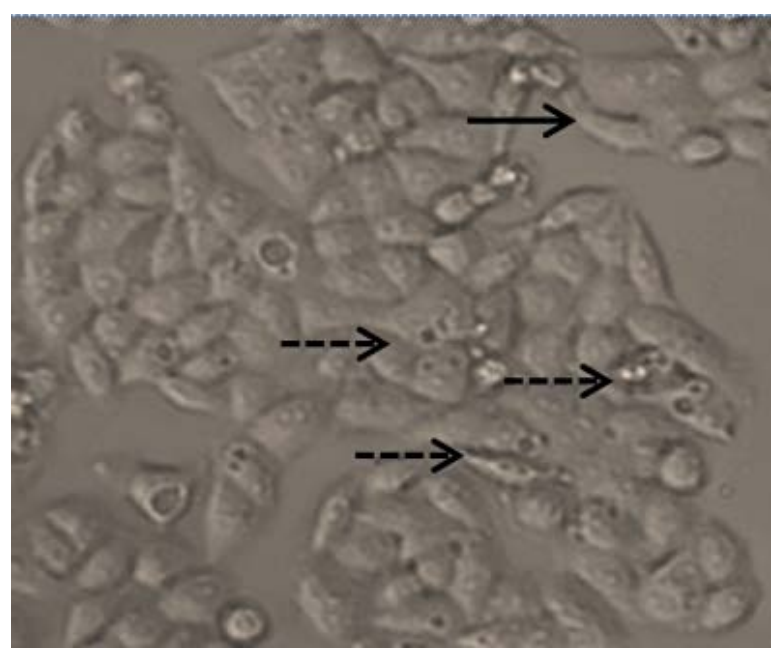

B2

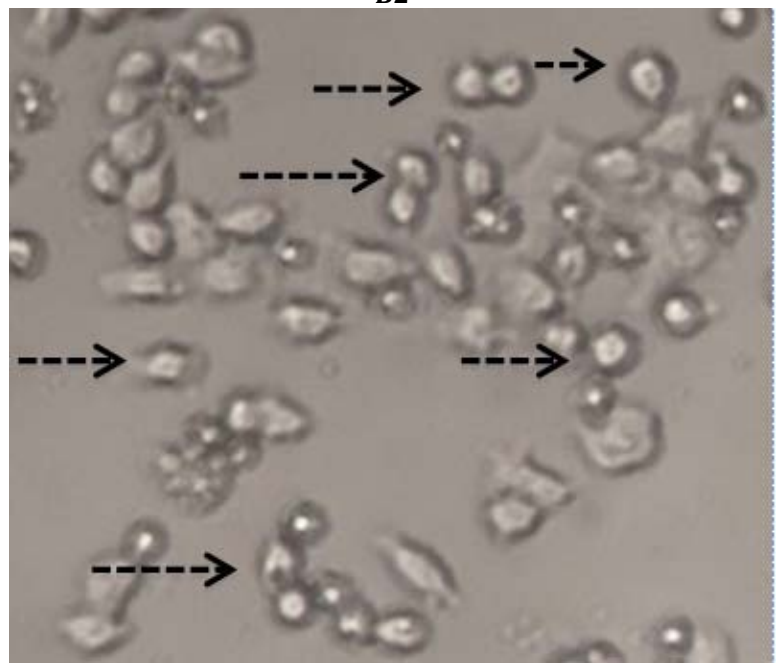

B4

Fig. 5: Effect of Brazilein on MCF-7/DOX Cell Viability (A). Cell viability diagram was obtained from average \pm standard of error (SE) with $\mathrm{n}=3$. The cytotoxic effect images of untreated control MCF-7/DOX cells (B1); after $24 \mathrm{~h}$ Brazilein $10 \mu \mathrm{M}$ (B2); Brazilein $25 \mu \mathrm{M}$ (B3);

\section{Brazilein $50 \mu \mathrm{M}$ treated MCF-7/DOX cells (B4), $\rightarrow$ normal cell morphology,,$\cdot \rightarrow$ change in cell morphology}

\section{DISCUSSION}

According to Teng et al. (2005) [22], compounds with $\mathrm{IC}_{50}$ values below $50 \mu \mathrm{M}$ had a potent cytotoxicity against cancer cells, meaning brazilein had cytotoxic effect in MCF-7/DOX cells and brazilein performed as a potent chemopreventive agent. This effect was supported by the morphological changing such as cell nuclei appear shrunken, irregular morphology and some cells undergo membrane blebbing.
The cytotoxic effect of brazilein on MCF-7/DOX cells might be caused by cell cycle arrest or apoptosis induction. Therefore, further study must be conducted to evaluate the molecular mechanism that contributes to brazilein's potency as an anticancer agent against MCF-7/DOX cells by using in silico. This study has been held to describe the molecular mechanism of brazilein and Pgp protein as protein target by evaluating the score docking. Score docking shows interaction strength of active compound and 
protein target. Lower score docking means higher binding affinities between them. Molecular docking analysis of brazilein was a bond in ATP binding site of Pgp. Pgp is an energy (ATP)dependent protein transporter [23].

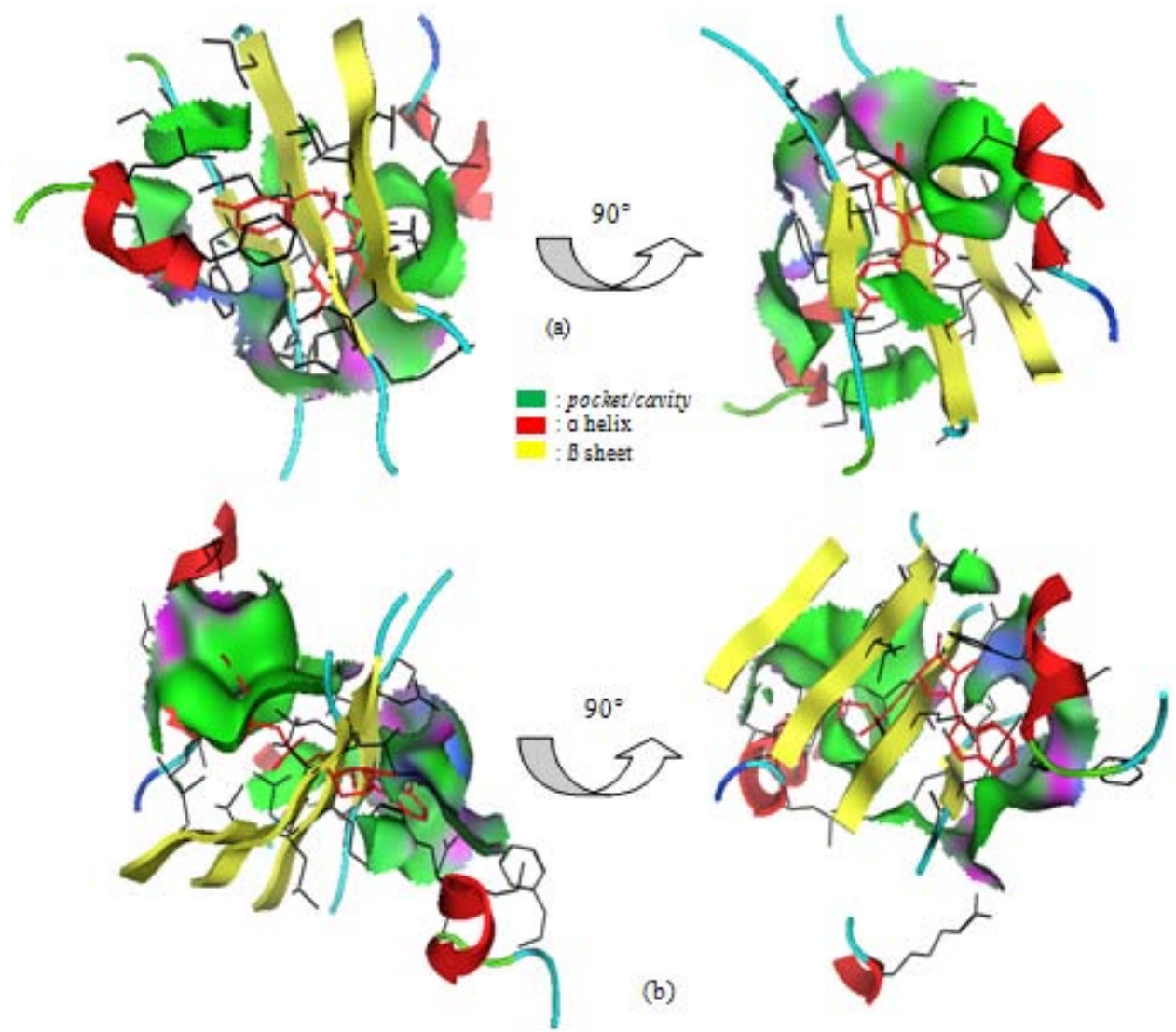

Fig. 6: Docking representations of brazilein and ATP interaction in ATP binding site to Pgp target proteins using PLANTS. The 3D interaction between brazilein and ATP binding site of Pgp (1MV5) (a); Interaction between ATP and ATP binding site of Pgp (1MV5)

Here, this study demonstrated that brazilein exhibited promising anticancer activity on resistance cancer cases through ATP binding inhibition in ATP binding site of Pgp (fig. 6). This inhibition disrupts Pgp activity because there was not enough energy to be used in active transport process by Pgp [24]. That interaction happens through hydrogen bonding between $\mathrm{O}$ atom in carbonyl group of $\mathrm{C}_{9}$ atom of brazilein with $\mathrm{H}$ atom in Ser 423, Leu 504 and Asp 505 amino acid residu of Pgp protein target (table 3). ATP interacted in ATP binding site of Pgp (fig. 6b) associated between hydrogen bonding of $\mathrm{H}$ atom in ATP with $\mathrm{O}$ atom in Phe 421 and Leu 533 amino acid residu of Pgp (table 3). The further study must be held to explore the molecular mechanism of brazilein in vitro associated with inhibition of brazilein in Pgp activation.

\section{CONCLUSION}

Fraction II which has the intense reddish color crystal, identified as brazilein based on the characterization of the purified component obtained from vacuum column chromatography result and brazilein had a potent cytotoxicity against MCF-7/DOX cells with $\mathrm{IC}_{50}$ value was $43 \mu \mathrm{M}$ by inhibition of P-glycoprotein (pgp).

\section{ACKNOWLEDGEMENT}

The authors would like to thank to Universitas Gadjah Mada and Cancer Chemoprevention Research Center (CCRC) for the assistance of both material and non-material for the implementation of this research.

\section{AUTHORS CONTRIBUTION}

Linda Laksmiani isolated brazilein using a flash column with guidance by Ratna Susidarti. Evaluation of brazilein cytotoxic activity as well as its molecular mechanism with guidance and advice by Edy Meiyanto. All authors contributed ideas and thoughts to the writing of this paper.

\section{CONFLICT OF INTERESTS}

\section{Declared none}

\section{REFERENCES}

1. Lioe HN, Adawiyah DR, Anggraeni R. Isolation and characterization of the major natural dyestuff component of Brazilwood (Caesalpinia sappan L.). Int Food Res J 2012;19:537-42.

2. Ye M, Xie WD, Lei F, Meng Z, Zhao YN, Su H, et al. Brazilein, an important immunosuppressive component from Caesalpinia sappan L. Int J Immunopharmacol 2006;6:426-32.

3. Hu J, Yan X, Wang W, Wu H, Hua L, Du L. Antioxidant activity in vitro of three constituents from Caesalpinia sappan L. Tsinghua Sci Technol 2008;13:474-9.

4. Lim MY, Jeon JH, Jeong EY, Lee CH, Lee HS. Antimicrobial activity of 5-hydroxy-1,4-naphthoquinone isolated from Caesalpinia sappan toward intestinal bacteria. Food Chem 2007;100:1254-8.

5. Batubara I, Mitsunaga T, Ohashi H. Brazilin from Caesalpinia sappan wood as an antiacne agent. J Wood Sci 2009;56:77-81.

6. Zhong B, Wu YJ Pan, S Zheng. Brazilein inhibits survivin protein and mRNA expression and induces apoptosis in hepatocellular carcinoma HepG2 cells. Neoplasma 2009;56:387-92.

7. Lim DK, U Choi, DH Shin. Antioxidative activity of some solvent extract from Caesalpinia sappan Linn, Korean J. Food Sci Technol 1997;28:77-82. 
8. Yen C, Kyoko Nakagawa-Goto, Tsong-Long Hwang, Pei-Chi Wu, Susan L Morris-Natschke, Wan-Chun Lai, et al. Antitumor agents. 271. total synthesis and evaluation of brazilein and analogs as anti-inflammatory and cytotoxic agents. Bioorg Med Chem Lett 2010;20:1037-9.

9. Tao LY, Li JY, Zhang JY. Brazilein, a compound isolated from Caesalpinia sappan Linn., induced growth inhibition in breast cancer cells via involvement of GSK-3 $\beta / \beta$-Catenin/cyclin D1 pathway. Chem Biol Interact 2013;206:1-5.

10. Laksmiani NPL, Susidarti RA, Meiyanto E. Brazilein increases the sensitivity of doxorubicin on MCF-7 resistant doxorubicin (MCF-7/DOX) cells through inhibition of HER-2 activation. Int J Pharm Pharm Sci 2015;7:525-8.

11. Byun SS, Kim SW, Choi H, Lee C, Lee E. Augmentation of cisplatin sensitivity in cisplatin-resistant human bladder cancer cells by modulating glutathione concentrations and glutathione-related enzyme activities. BJU Int 2005;95: 1086-90.

12. Stavrovskaya AA, Stromskaya TP. Transport proteins of the ABC family and multidrug resistance of tumor cells. Biochemistry (Moscow) 2008;73 :592-604.

13. Chung SY, Sung MK, Kim NH, Jang JO, Go EJ, Lee HJ. Inhibition of P-glycoprotein by natural products in human breast cancer cells. Arch Pharm Res 2005;28:823-8.

14. Wong HL, Bendayan R, Rauth AM, Xue HY, Babakhanian K, Wu XY. A mechanistic study of enhanced doxorubicin uptake and retention in multidrug resistant breast cancer cells using a polymer-lipid hybrid nanoparticle system. J Pharmacol Exp Ther 2006;317:1372-81.

15. Putri DDP, Sarmoko, Febriansah R. MCF-7 resistant doxorubicin are characterized by lamellipodia, strong adhesion on the substrate and Pgp overexpression. Indo J Can Chemoprev 2013;2:304-8.

16. Skoog DA, Holler FJ, Crouch SR. Principles of instrumental analysis. Sixth Edition. Thomson Higher Education, Canada USA; 2007.

17. Pavia DL, Lampman GM, Kriz GS. Introduction to spectroscopy. $2^{\text {nd }}$ ed. Philadelphia: Harcourt Brace College Publ; 1996. p. 511.

18. Oliveira LFC, Edwards HGM, Velozo ES, Nesbitt M. Vibrational spectroscopic study of Brazilin and Brazilein, the main constituents of brazilwood from Brazil. Vibrational Spectroscopy 2002;28:243-9.

19. Kim DS, Baek NI, Jung KY, Lee IS, Lee HK. NMR assignment of Brazilein. Phytochemistry 1997;46:177-8.

20. Rosenberg E. Characterisation of historical organic dyestuffs by liquid chromatography-mass spectrometry. Anal Bioanal Chem 2008;391:33-57.

21. Gajjar DG, Patel RM, Patel VA, Patel PKM. Novel hydroxyl terminated dendrimers as potential drug carriers: sustained release, hemolysis and cytotoxicity study. Int J Appl Pharm 2015;7:5-9.

22. Teng WY, Yu LH, Chien CS, Ray LH. Cytotoxic acridone alkaloids from te stem bark of citrus maxima. J Chin Chem Soc 2005;52:1253-5.

23. Sanneboina S, Sammeta V, Pingili RB, Kadimpati KK. Influence of lovastatin on pharmacokinetics and pharmacodynamics of glipizide in healthy and streptozotocin-induced diabetic rats: involvement of p-glycoprotein inhibition. Asian J Pharm Clin Res 2016;9:3-8.

24. Aller SG, Yu J, Ward A, Weng Y, Chittaboina S, Zhou R, et al. Structure of P-glycoprotein reveals a molecular basis for polyspecific drug binding. Science 2012;323:171-2. 